\title{
The Role of Economic Diplomacy in Increasing the Value of Exports to Mediterranean Countries - The Case of Slovenia
}

Dejan Romih

University of Maribor, Faculty of Economics and Business, Slovenia dejan.romih@uni-mb.si

\author{
Klavdij Logožar \\ University of Maribor, Faculty of Economics and Business, Slovenia \\ klavdij.logozar@uni-mb.si
}

Doi:10.5901/ajis.2014.v3n3p100

\begin{abstract}
This paper examines the role of economic diplomacy, which is the activity of managing economic relationships between countries, in increasing the value of exports to Mediterranean countries in the case of Slovenia. Additionally, it also examines the role of economic promotion (especially trade promotion), which is one of the main activities of economic diplomacy, in increasing exports to the aforesaid countries in the same case. However, neither economic diplomacy nor economic promotion are panaceas for economic mismanagement, which is one of the main reasons for the current financial and economic crisis in Slovenia and certain other countries, mainly in Southern Europe.
\end{abstract}

Keywords: economic diplomacy, economic promotion, foreign trade, Mediterranean countries, Slovenia.

\section{Introduction}

Diplomacy is the activity of managing relationships between countries (see, e.g., Freeman, 1997; Berridge \& James, 2001; Rana, 2002; Jönsson \& Hall, 2005; Barston, 2006; Bolewski, 2007; Jazbec, 2009; Berridge, 2010; Pigman, 2010; Siracusa, 2010; Hamilton \& Langhorne, 2011; Bjola \& Kornprobst, 2013; Cooper, Heine \& Thakur, 2013). There are several types of diplomacy, some of which are more important than others. One is economic diplomacy, which is the activity of managing economic relationships between countries (see, e.g., Bergeijk, 2009; Veenstra, Yakop \& Bergeijk, 2010; Bayne \& Woolcock, 2011a; Bayne \& Woolcock, 2011b; Bergeijk, Okano-Heijmans \& Melissen, 2011; Larson, 2011; Verhagen \& Bleker, 2011; Romih, 2013a; Romih, 2013b; Woolcock \& Bayne, 2013). Economic diplomacy is becoming increasingly important for Slovenia (Jaklič, 2010; Samec \& Romih, 2010; Žbogar, 2010; Gasparič, 2011; Sovič, 2012; Erjavec, 2013, Erjavec, 2014). There are several reasons for this. One is the current financial and economic crisis, which is continuing to affect its economy. Slovenia thus faces certain economic and social problems. Foremost among these is increased unemployment. Additional measures are therefore needed to promote employment and the social inclusion of unemployed people. These measures are also needed to prevent the migration of people from Slovenia to other countries, mainly in Europe and North America. In 2012, 14,378 people emigrated from Slovenia, which is an increase of 19.6 per cent over the previous year; nearly three-quarters of them were aged 25-64 (Statistical Office of the Republic of Slovenia, 2013a). Among these, 59.9 per cent were employed prior to emigration. Most of them immigrated to a European country, mainly Austria, Germany, Croatia and Bosnia and Herzegovina, the latter two being Mediterranean countries.

\section{Economic Promotion}

Economic promotion is the activity of promoting an economy. It is very important for countries, regions, cities, etc., due to its impact on their economic performance. This is one of the reasons why economic promotion is so important for Slovenia (Romih \& Logožar, 2011a, p. 135; A. Cantarutti, personal communication, 7 January 2014), whose economy is still in crisis.

Economic promotion is the main activity of economic diplomacy (Pigman, 2010, p. 69; Rana \& Chatterjee, 2011, pp. 6-9). One reason for this is that this type of promotion may assist in the achievement of goals such as increasing the value of exports. Economic diplomacy is, therefore, becoming increasingly important for countries whose economic 
growth is driven by exports, as is the case with Slovenia. Increasing exports is, therefore, very important to improving economic performance. Other measures are also needed, such as the promotion of cooperation between companies (especially small- and medium-sized ones) in entering foreign markets (Cantarutti, 2012).

There are several types of economic promotion, such as trade and investment promotion (see, e.g., United Nations, 2009; Naray, 2011; Mills, 2013). Trade and investment promotion are essential for a country in accelerating its foreign trade and investment. This is one of the reasons why trade and investment promotion are becoming increasingly important for countries affected by the current financial and economic crisis.

\section{Trade Promotion}

Foreign trade is the activity of trading goods and services with other countries. It is very important for Slovenia, contributing to its economic growth and development (the main goals of its economic policies) (Romih, 2013b, p. 95; Cantarutti, 2014). Trade promotion, which is the activity of promoting foreign trade, is essential to achieving these goals; this is one of the reasons why trade promotion has become an important activity of Slovenia's diplomatic and consular representatives.

Slovenia is heavily dependent on trade with other European countries (see Figure 1), mainly Austria, Italy and Germany (see Figure 2). Foreign trade diversification is thus essential in order to accelerate Slovenia's foreign trade. It is also essential to accelerate Slovenia's economic growth and development in order to restore economic stability (which, in addition to political stability, is essential for peace and prosperity). Removing trade barriers is, therefore, crucial for achieving these goals. However, the policies directed at these goals are more or less inconsistent, making them ineffective and inefficient and leaving Slovenia less competitive by comparison to some other countries. Estonia, for example, ranks $32^{\text {nd }}$ out of 148 countries according to the Global Competitiveness Index 2013-2014, which is 30 rankings higher than Slovenia (Schwab, 2013, p. 15). This requires immediate action at all levels of governance (Romih, 2013c). In order to become more competitive, Slovenia needs to carry out economic reforms, which should be consistent in order to become more effective and efficient (Romih \& Samec, 2010; Romih, 2013a, p. 101). This is integral to increasing public confidence in these reforms (especially during the current financial and economic crisis) and to creating an environment conducive to the economic reforms necessary if the country is to adapt to changing economic conditions at home and abroad. Furthermore, it is vital to accelerate Slovenia's foreign trade in order to improve labour market conditions and stop the 'brain drain' to more competitive countries (e.g., Austria, Germany and Switzerland). This is another reason for Slovenia to accelerate its trade promotion.

In 2012, the value of Slovenia's exports of goods to European countries amounted to 18.9 billion euros (Statistical Office of the Republic of Slovenia, 2013, p. 398), which is a decrease of 0.7 per cent over the previous year. In the same year, the value of Slovenia's exports of goods to non-European countries amounted to 2.2 billion euros, an increase of 9.5 per cent over the previous year. The main importers of goods from Slovenia among non-European countries were Algeria, Turkey and the United States of America. Also in 2012, the value of Slovenia's imports of goods from European countries amounted to 19.1 billion euros (ibid., p. 398), which is a decrease of 2.5 per cent over the previous year, while the value of its imports of goods from non-European countries amounted to 3 billion euros, an increase of 0.7 per cent over the previous year. China, the Republic of Korea and the United States of America were the main exporters of goods to Slovenia among non-European countries.

Figure 1: Slovenia's exports and imports by country groups, 2009-2012

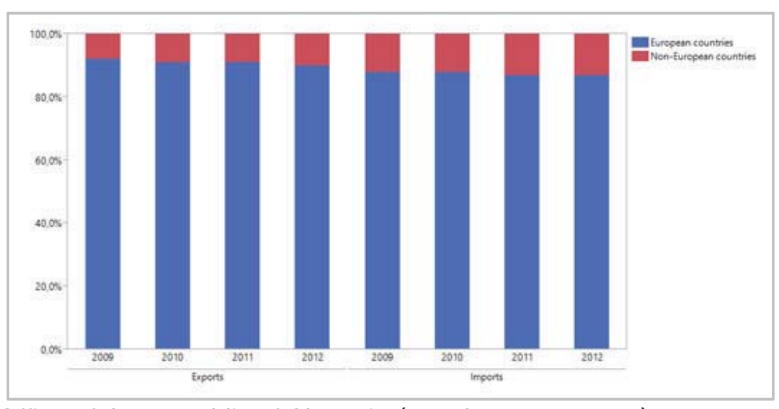

Source of data: Statistical Office of the Republic of Slovenia (2013b, pp. 398-402). 
Figure 2: Slovenia's exports and imports by European countries, 2012

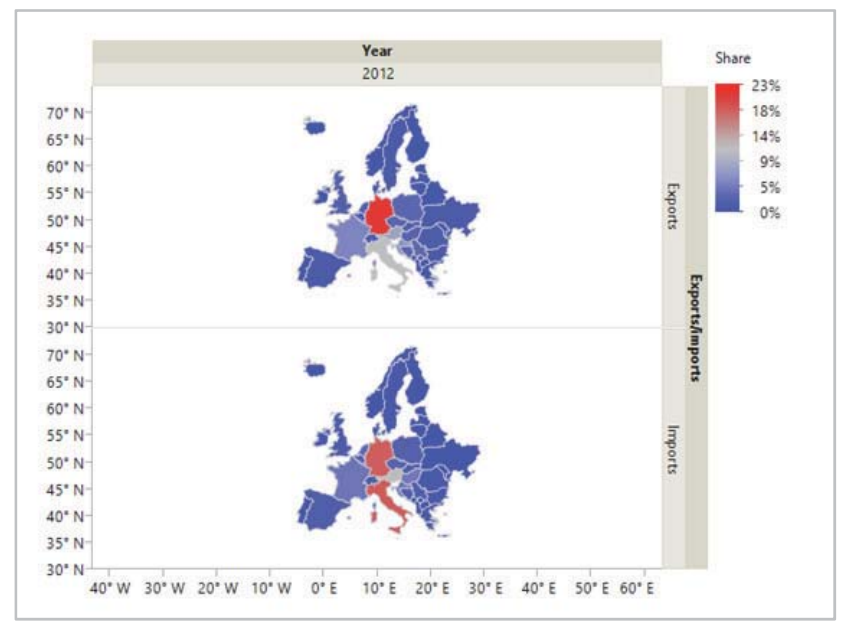

Source of data: Statistical Office of the Republic of Slovenia (2013b, pp. 398-402).

Austria, Italy and Germany are the three main trade partners of Slovenia. In 2012, the value of Slovenia's exports of goods to these countries amounted to 8.6 billion euros, which is 40.7 per cent of the value of Slovenia's exports of goods (see Figure 3) and 45.3 per cent of the value of Slovenia's exports of goods to European countries. In the same year, the value of Slovenia's imports of goods from Austria, Italy and Germany amounted to 10.8 billion euros, which is 48.7 per cent of the value of Slovenia's imports of goods (see Figure 3) and 56.2 per cent of the value of Slovenia's imports of goods from European countries.

Figure 3: Slovenia's exports and imports by country groups, 2012

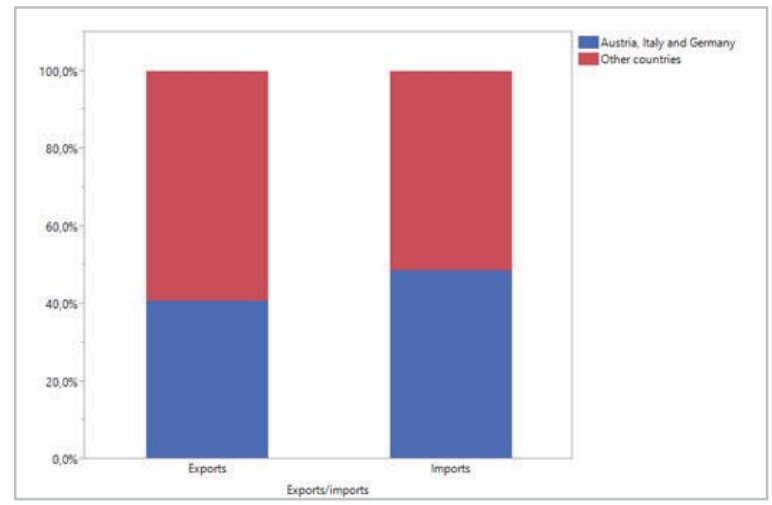

Source of data: Statistical Office of the Republic of Slovenia (2013b, pp. 398-402).

Italy, Croatia and France are the three main Mediterranean trade partners of Slovenia. In 2012, the value of Slovenia's exports of goods to these countries amounted to 4.9 billion euros, which is 23.2 per cent of the value of Slovenia's exports of goods (see Table 1) and 74.5 per cent of the value of Slovenia's exports of goods to Mediterranean countries. In the same year, the value of Slovenia's imports of goods from Italy, Croatia and France amounted to 6.0 billion euros, which is 27.2 per cent of the value of Slovenia's imports of goods (see Table 1) and 82.1 per cent of the value of Slovenia's imports of goods from Mediterranean countries. 
Table 1: Slovenia's exports and imports of goods by Mediterranean countries, 2012

\begin{tabular}{|l|c|c|c|c|c|}
\hline & \multicolumn{2}{|c|}{ Slovenia's exports of goods } & \multicolumn{2}{c|}{ Slovenia's imports of goods } & $\begin{array}{c}\text { Slovenia's exports as a } \\
\text { percentage of Slovenia's imports }\end{array}$ \\
\hline & $\begin{array}{c}\text { Thousand } \\
\text { euros }\end{array}$ & $\begin{array}{c}\text { Per cent of } \\
\text { total }\end{array}$ & $\begin{array}{c}\text { Thousand } \\
\text { euros }\end{array}$ & $\begin{array}{c}\text { Per cent of } \\
\text { total }\end{array}$ & \\
\hline Albania & 37607 & 0.2 & 571 & 0.0 & 6586.2 \\
\hline Algeria & 216173 & 1.0 & 77488 & 0.4 & 278.0 \\
\hline $\begin{array}{l}\text { Bosnia and } \\
\text { Herzegovina }\end{array}$ & 583519 & 2.8 & 364804 & 1.7 & 160.0 \\
\hline Croatia & 1356693 & 6.4 & 943463 & 4.3 & 143.8 \\
\hline Cyprus & 31707 & 0.2 & 18893 & 0.1 & 167.8 \\
\hline Egypt & 40035 & 0.2 & 16928 & 0.1 & 236.5 \\
\hline France & 1159077 & 5.5 & 947921 & 4.3 & 122.3 \\
\hline Gibraltar & 10 & 0.0 & 9 & 0.0 & 111.1 \\
\hline Greece & 58055 & 0.3 & 127255 & 0.6 & 45.6 \\
\hline Israel & 35970 & 0.2 & 20807 & 0.1 & 172.9 \\
\hline Italy & 2380316 & 11.3 & 4108058 & 18.6 & 164.9 \\
\hline Lebanon & 6151 & 0.0 & 3746 & 0.0 & 116150.0 \\
\hline Libya & 55752 & 0.3 & 48 & 0.0 & 274.1 \\
\hline Malta & 6971 & 0.0 & 2543 & 0.0 & 0.0 \\
\hline Monaco & 0 & 0.0 & 0 & 0.0 & 331.2 \\
\hline Montenegro & 85270 & 0.4 & 25749 & 0.1 & 940.0 \\
\hline Morocco & 21958 & 0.1 & 2336 & 0.0 & 0.0 \\
\hline Palestine & 73 & 0.0 & 0 & 0.0 & 112.6 \\
\hline Portugal & 42405 & 0.2 & 37653 & 0.2 & 53.1 \\
\hline Spain & 211781 & 1.0 & 398919 & 1.8 & 818.3 \\
\hline Syria & 6023 & 0.0 & 736 & 0.0 & 142.4 \\
\hline Tunisia & 22101 & 0.1 & 15517 & 0.1 & 106.2 \\
\hline Turkey & 210463 & 1.0 & 198104 & 0.9 & 89.8 \\
\hline Mediterranean & 6568110 & 31.2 & 7311548 & 33.1 & \\
\hline countries & & & & & \\
\hline & & & & & \\
\hline
\end{tabular}

Source of data: Statistical Office of the Republic of Slovenia (2013b, pp. 398-402).

\section{Investment Promotion}

Investment promotion, which is the activity of promoting foreign investment, is a type of economic promotion. It is very important for a country for several reasons. One is the impact of foreign investment on a country's economic growth and development. For Slovenia, foreign investment is particularly important because the country lacks domestic investment (Romih, 2013a). This is, to some extent, a result of the current financial and economic crisis, which is continuing to have a negative impact on Slovenia's investment climate. There are also certain other investment barriers in Slovenia. One is economic nationalism, which does not benefit Slovenia's economy (S. Dajčman, personal communication, 29 March 2014).

In 2012, the stock of inward foreign direct investment in Slovenia amounted to 15.5 billion US dollars at current prices and exchange rates (United Nations Conference on Trade and Development, 2014), which is an increase of 4.4 per cent over the previous year. In the same year, the stock of outward foreign direct investment in Slovenia amounted to 7.8 billion US dollars at current prices and exchange rates (ibid.), a decrease of 0.1 per cent over the previous year.

\section{Tourism Promotion}

Tourism promotion is also very important for a country. There are several reasons for this. One is the impact of tourism on a country's foreign trade and investment (see, e.g., Pigman, 2010, p. 93). For Slovenia, tourism is particularly important because it is one of the economic activities which has been least affected by the current financial and economic crisis. In 2012, 2.2 million arrivals of foreign tourists were registered in tourist accommodations in Slovenia (Statistical Office of the Republic of Slovenia, 2013b, p. 423), which is an increase of 5.8 per cent over the previous year. In the 
same year, 5.8 million overnight stays were registered in tourist accommodations in Slovenia (ibid., p. 423), an increase of 5.7 per cent over the previous year. Most foreign tourists in Slovenia were from Austria, Italy and Germany, who are the three main trade partners of Slovenia.

\section{Conclusion}

Slovenia is a small country which faces particular economic and social problems, such as increased unemployment (especially among young people). There are several reasons for this. One is ongoing economic mismanagement, which has had a negative impact on Slovenia's economic performance. Economic diplomacy, which has the opposite impact on a country's economic performance, is therefore very important for Slovenia and its stakeholders.

\section{Acknowledgements}

The author would like to express its gratitude to Viktor Baraga (Consulate of Australia), Aleš Cantarutti (Chamber of Commerce and Industry of Slovenia, Centre for International Business), Klavdij Logožar (University of Maribor, Faculty of Economics and Business, Department of International Economics and Business), Arne Mislej (Consulate of the Republic of Indonesia), Žan Jan Oplotnik (University of Maribor, Faculty of Economics and Business, Department of Finance), Tomáš Siviček (Jan Evangelista Purkyně University in Ústí nad Labem, Faculty of Social and Economic Studies, Department of Economics) and Janez Šumrada (Ministry of Foreign Affairs of the Republic of Slovenia, Directorate for Economic Diplomacy) for their views on economic promotion.

\section{References}

Barston, R. P. (2006). Modern diplomacy, $3^{\text {rd }}$ ed. Harlow: Pearson/Longman.

Bayne, N. \& Woolcock, S. (2011a). The future of economic diplomacy. In N. Bayne \& S. Woolcock (eds.), The new economic diplomacy: decision-making and negotiating in international economic relations, $3^{\text {rd }}$ ed. Farnham: Ashgate Publishing, pp. 359-378.

Bayne, N. \& Woolcock, S. (2011b). What is economic diplomacy? In N. Bayne \& S. Woolcock (eds.), The new economic diplomacy: decision-making and negotiating in international economic relations, $3^{\text {rd }}$ ed. Farnham: Ashgate Publishing, pp. 1-15.

Bergeijk, P. A. G. van, Okano-Heijmans, M. \& Melissen, J. (eds.). (2011). Economic diplomacy: economic and political perspectives. Leiden: Martinus Nijhoff Publishers.

Bergeijk, P. A. G. van. (2009). Economic diplomacy and the geography of international trade. Cheltenham: Edward Elgar Publishing.

Berridge, G. R. \& James, A. (2001). A dictionary of diplomacy. Basingstoke: Palgrave Macmillan.

Berridge, G. R. (2010). Diplomacy: theory and practice, $4^{\text {th }}$ ed. Basingstoke: Palgrave Macmillan.

Bjola, C. \& Kornprobst, M. (2013). Understanding international diplomacy: theory, practice and ethics. Oxford: Routledge.

Bolewski, W. (2007). Diplomacy and international law in globalized relations. New York: Springer.

Cantarutti, A. (2012). Mednarodno poslovanje slovenskih podjetij v času finančne in gospodarske krize. Speech given at the Seminar on Economic Diplomacy, Maribor, Slovenia, 2nd March 2012.

Cantarutti, A. (2014). Mednarodno poslovanje slovenskih podjetij v času finančne in gospodarske krize. Lecture held at the University of Maribor, Faculty of Economics and Business, Maribor, Slovenia, $7^{\text {th }}$ January 2014.

Cooper, A. F., Heine, J. \& Thakur, R. (eds.) (2013). The Oxford handbook of modern diplomacy. Oxford: Oxford University Press.

Erjavec, K. V. (2013). Keynote address. Keynote address delivered at the $2^{\text {nd }}$ International 2-day Conference on Economic Diplomacy and Internationalisation, Ljubljana, Slovenia, $17^{\text {th }}$ June 2013.

Erjavec, K. V. (2014). Keynote address. Keynote address delivered at the $18^{\text {th }}$ Consultations of Slovenian diplomats. Brdo pri Kranju, Slovenia, 6 January 2014.

Freeman, C. W. (1997). Arts of power: statecraft and diplomacy. New York: United States Institute of Peace.

Gasparič, V. (2011). Gospodarska diplomacija in razvojno sodelovanje. Speech given at the Seminar on Economic Diplomacy. Maribor, Slovenia, $16^{\text {th }}$ March 2011.

Hamilton, K. \& Langhorne, R. (2011). The practice of diplomacy: its evolution, theory and administration, $2^{\text {nd }}$ ed. London: Routledge.

Jaklič, A. (2010). Challenges of economic diplomacy in a time of crisis. Speech given at the $21^{\text {st }}$ Slovenian Political Science Conference. Portorož, Slovenia, 27 th May 2010.

Jazbec, M. (2009). Osnove diplomacije. Ljubljana: Fakulteta za družbene vede.

Jönsson, C. \& Hall, M. (2005). Essence of diplomacy. Basingstoke: Palgrave Macmillan.

Korez-Vide, R. (2013). Trgovinska geografija. Speech given at the Winter School on Economic Geography, Maribor, Slovenia, 20 th December 2013.

Larson, A. (2011). U.S. economic diplomacy: the next 50 years. Foreign Service Journal, 88(2), pp. 17-24.

Mills, G. (2013). Trade and investment promotion. In E. F. Cooper, J. Heine \& R. Thakur (eds.), The Oxford handbook of modern diplomacy Oxford: Oxford University Press, 2013, pp. 402-418.

Naray, O. (2011). Commercial diplomats in the context of international business. In P. A. G. van Bergeijk, M. Okano-Heijmans \& J. 
Melissen (eds.), Economic diplomacy: economic and political perspectives. Leiden: Martinus Nijhoff Publishers, pp. 121-148.

Pigman, G. A. (2010). Contemporary diplomacy: representation and communication in a globalized world. Oxford: Polity Press.

Rana, K. S. (2002). Bilateral diplomacy. Geneva: DiploHandbooks.

Rana, S. \& Chatterjee, B. (2011). Introduction: the role of embassies. In K. S. Rana \& B. Chatterjee (eds.), Economic diplomacy: India's experience. Jaipur: CUTS International, pp. 3-25.

Romih, D. \& Logožar, K. (2011a). Pomen gospodarske diplomacija za izhod iz krize in nadaljnji razvoj slovenskega gospodarstva. Lexonomica, 3(1), pp. 113-115.

Romih, D. \& Logožar, K. (2011b). Vloga častnih konzulov v gospodarske diplomacija. Speech given at the Seminar on Economic Diplomacy. Maribor, Slovenia, $2^{\text {nd }}$ April 2011.

Romih, D. \& Samec, N. 2010. Transition and transition related labour market changes in the new EU Member States and the Western Balkans in the light of the world financial and economic crisis: economic and legal perspective. Speech given at the $29^{\text {th }}$ International Conference on Organizational Science Development. Portorož, Slovenia, 26 $6^{\text {th }}$ March 2010.

Romih, D. (2013a). Gospodarska diplomacija in varnost v času krize. Lexonomica, 5(1), pp. 100-102.

Romih, D. (2013b). The role that economic diplomacy and security play in a time of crisis - the case of Slovenia. International Journal of Scientific Research, 2(8), pp. 95-96.

Romih, D. (2013c). Gospodarska geografija. Speech given at the Winter School on Economic Geography. Maribor, Slovenia, 20th December 2013.

Samec, N. \& Romih, D. (2010). Economic diplomacy in the light of the world financial and economic crisis. Speech given at the $21^{\text {st }}$ Slovenian Political Science Conference. Portorož, Slovenia, 27 $7^{\text {th }}$ May 2010.

Schwab, K. (Ed.). (2013). The global competitiveness report 2013-2014. Geneva: World Economic Forum.

Siracusa, J. M. (2010). Diplomacy: a very short introduction. Oxford: Oxford University Press.

Sovič, B. (2012). Gospodarska diplomacija. Speech given at the Seminar on Economic Diplomacy. Maribor, Slovenia, $2^{\text {nd }}$ March 2012.

Statistical Office of the Republic of Slovenia. (2013a). Socioeconomic characteristics of international migrants, Slovenia, 2012 - final data. Retrieved from: http://www.stat.si/eng/novica_prikazi.aspx?id=5956. Accessed: $28^{\text {th }}$ March 2013.

Statistical Office of the Republic of Slovenia. (2013b). Statistical yearbook of the Republic of Slovenia 2013. Ljubljana: Author.

United Nations Conference on Trade and Development. (2014). Inward and outward foreign direct investment stock, annual, $1980-2012$. Retrieved from: http://unctadstat.unctad.org/TableViewer/tableView.aspx?Reportld=89. Accessed: 30th March 2013.

United Nations. (2009). Promoting investment and trade: practices and issues. New York: Author.

Veenstra, M.-L. E. H. van, Yakop, M. \& Bergeijk, P. A. G. van. (2010). Economic diplomacy, the level of development and trade. Clingendael Discussion Papers in Diplomacy, no. 119. Clingendael: Netherlands Institute of International Relations.

Verhagen, M. \& Bleker, H. (2011). Economic diplomacy in a changing world. In P. A. G. van Bergeijk, M. Okano-Heijmans \& J. Melissen (eds.), Economic diplomacy: economic and political perspectives. Leiden: Martinus Nijhoff Publishers, pp. 171-186.

Woolcock, S. \& Bayne, N. (2013). Economic diplomacy. In E. F. Cooper, J. Heine \& R. Thakur (eds.), The Oxford handbook of modern diplomacy. Oxford: Oxford University Press, pp. 385-401.

Žbogar, S. (2010). Keynote address. Keynote address delivered at the $21^{\text {st }}$ Slovenian Political Science Conference. Portorož, Slovenia, $27^{\text {th }}$ May 2010. 